\title{
CAMA
}

Centre for Applied Macroeconomic Analysis

\section{Terms of Trade Volatility, Government Spending Cyclicality, and Economic Growth}

\section{CAMA Working Paper 36/2016 June 2016}

\section{Markus Brueckner}

Centre for Applied Macroeconomic Analysis, ANU

\section{Francisco Carneiro}

The World Bank

\section{Abstract}

This paper presents estimates of the effects that terms of trade volatility has on real GDP per capita growth. Based on 5-year non-overlapping panel data comprising 175 countries during 1980-2010, the paper finds that terms of trade volatility has significant adverse effects on economic growth in countries with procyclical government spending; in countries where government spending is countercyclical terms of trade volatility has no significant effect on growth. Conditional on the mediating role of government spending cyclicality, the GDP share of domestic credit to the private sector has no significant effect on the relationship between growth and terms of trade volatility. 


\section{Keywords}

\section{JEL Classification}

\section{Address for correspondence:}

(E) cama.admin@anu.edu.au

ISSN 2206-0332

The Centre for Applied Macroeconomic Analysis in the Crawford School of Public Policy has been established to build strong links between professional macroeconomists. It provides a forum for quality macroeconomic research and discussion of policy issues between academia, government and the private sector.

The Crawford School of Public Policy is the Australian National University's public policy school, serving and influencing Australia, Asia and the Pacific through advanced policy research, graduate and executive education, and policy impact. 


\title{
Terms of Trade Volatility, Government Spending Cyclicality, and Economic Growth
}

\author{
Markus Brueckner \\ Australian National University \\ and \\ Francisco Carneiro \\ The World Bank
}

\begin{abstract}
This paper presents estimates of the effects that terms of trade volatility has on real GDP per capita growth. Based on 5-year non-overlapping panel data comprising 175 countries during 1980-2010, the paper finds that terms of trade volatility has significant adverse effects on economic growth in countries with procyclical government spending; in countries where government spending is countercyclical terms of trade volatility has no significant effect on growth. Conditional on the mediating role of government spending cyclicality, the GDP share of domestic credit to the private sector has no significant effect on the relationship between growth and terms of trade volatility.
\end{abstract}




\section{Introduction}

Variation in terms of trade volatility, across countries and time, is significant. Figure 1 plots the 5year standard deviation of the annual growth rate of the terms of trade during the past three decades for a sample of 175 countries. The figure shows that for the average country terms of trade volatility has generally declined since the 1980s, although there has been a spike in recent years. Figure 2 shows that the variation across countries' terms of trade volatility is substantial, and larger in the cross-section than in the time series.

Understanding the macroeconomic consequences of terms of trade volatility represents one of the key challenges facing policymakers. A commonly held view is that terms of trade volatility is associated with lower economic growth, especially in less developed economies. Terms of trade volatility in these countries leads to much more unstable growth paths than in developed economies. Moreover, by reducing economic growth in these countries, volatility can also affect future consumption. It is therefore not surprising that the welfare gains from reducing volatility in developing countries can be substantial (see, for instance, Athanasoulis and van Wincoop, 2000).

This paper presents panel estimates of the effects that terms of trade volatility has on economic growth. Theoretical literature, to be discussed in detail in Section 2, suggests that terms of trade volatility may have a negative effect on economic growth and that this effect may be exacerbated by procyclical government spending and financial underdevelopment. The use of panel data is suitable to test these hypotheses as there exists substantial variation in these variables across countries and time. Further, with panel data in hand we can employ rigorous panel data estimation techniques that control for country and time fixed effects. Controlling for these fixed effects enables to estimate within-country relationships.

Our panel data estimates suggest that terms of trade volatility has significant adverse effects on economic growth, but only in countries where government spending is procyclical. Based on 5year non-overlapping panel data comprising 175 countries during 1980-2010, and controlling for country and time fixed effects, we find that: (i) the average effect of terms of trade volatility on economic growth is not significantly different from zero; (ii) terms of trade volatility has significant adverse effects on economic growth in countries with procyclical government spending; (iii) conditional on the mediating role of government spending cyclicality, the GDP share of domestic credit to the private sector has no significant effect on the relationship between growth and terms of trade volatility. These findings suggest that the response of government spending to the business cycle plays an important role for the link between terms of trade volatility and economic growth. 
The GDP share of domestic credit to the private sector is tangential.

For macroeconomic models that aim to capture the link between terms of trade volatility and economic growth our empirical findings have two important implications. One implication is that feedback effects between the business cycle and government spending matter; assuming acyclical government spending leads to a significant loss in explanatory power. The second implication is that once the behavior of government spending is taken into account, financial (under)development as captured by (low values of) the GDP share of domestic credit to the private sector has immaterial benefits for purposes of modelling the link between terms of trade volality and economic growth.

The remainder of the paper is organized as follows. Next, we discuss the relevant literature to motivate the hypotheses that we are testing in the paper. Section 3 discusses the econometric approach. Section 4 describes the empirical findings. Section 5 concludes.

\section{Related Literature}

\section{Volatility}

The effect of volatility on output in the long-run depends on the presence of frictions in the economy. Lucas (1987) showed that, in the absence of frictions, the effect of business cycle fluctuations on output and welfare are trivial. One type of friction that can induce a negative effect of volatility on output are irreversibilities in investment. In the presence of irreversibilities in investment volatility induced by a greater variance of technology shocks will lead to lower investment and hence output (e.g., Bernanke, 1983; Pindyck, 1991). Policy volatility, too, can have a negative effect on investment and output growth as shown by Aizenman and Marion (1993) in a two-period general equilibrium model with investment irreversibilities. In a multi-sector model, volatility has a negative effect on output in the long-run if there are costs associated with moving factors across sectors, see, for example, Bertola (1994) and Dixit and Rob (1994)

As put by Jacks et al. (2011), there is an extensive literature that suggests that more volatility is bad for growth. Acemoglu et al. (2003) and Aghion et al. (2009) provide recent evidence. Mendoza (1997) proposes a strutural model in which terms of trade volatility affects growth and provides empirical evidence on this relation. Deaton (1999) emphasises the danger of commodity

price fluctuations in African economies. And Turnovsky and Chattopadhyay (2003) provide evidence that supports the proposition that volatility in the terms of trade and in the real exchange 
rate adversely affects growth.

Ramey and Ramey (1995) estimate the effect of volatility in a sample of 92 countries during 1960-1985. They find that volatility, measured as the standard deviation of GDP growth, has a significant negative effect on transitional growth and the long-run level of GDP per capita. The authors document that the effect of volatility on GDP per capita continues to be negative and significant when controlling for the investment share of GDP. Further, they show that volatility has no significant effect on the investment share of GDP.

Fatas and Mihov (2003) estimate the effect of government spending volatility and output volatility on economic growth. Based on a sample of 91 countries, they find that government spending volatility significantly increases output volatility and reduces growth. The authors document that political constraints significantly reduce government spending volatility. This finding they interpret as supporting the argument that political constraints are growth enhancing because they restrict discretionary fiscal policy. In a follow up paper, Fatas and Mihov (2013), expand the sample to 93 countries and confirm their original result that policy volatility reduces growth. In particular, they find that a one-standard-deviation increase in policy volatility reduces long-term economic growth by about $0.7 \%$ in the panel regressions, and by more than one percentage point in the cross-section.

An issue that arises when estimating the effect of output volatility and fiscal policy volatility on economic growth is that the former variables are endogenous. Hence, interpreting the above findings as providing evidence of a causal effect of volatility on growth is problematic. A step forward is to examine the impact in the volatility of exogenous shocks, such as fluctuations in the terms of trade and the weather.

Rodrick (1998) estimates the impact that terms of trade volatility has on government size. He finds that in countries more open to international trade terms of trade volatility leads to larger government size. Rodrick argues that larger government size provides a buffer against terms of trade shocks.

Brueckner and Gradstein (2013) examine the impact that rainfall volatility has on GDP volatility and government size. They find that rainfall volatility has a significant effect on GDP volatility in developing countries. Using rainfall volatility as an instrument for GDP volatility they find that the latter variable has a significant positive effect on government size. 


\section{Government Spending Cyclicality}

Government spending can mitigate the negative effect that volatility has on growth if: (i) government spending is counter-cyclical; and (ii) its impact on output is positive. For conceptual clarity it is useful to note that: (i) refers to the behavior of government spending, i.e. the response of government spending to the business-cycle; (ii) refers to the government spending multiplier, i.e. the effectiveness of government spending with regard to changing output. If government spending is pro-cyclical and the government spending multiplier is positive, then increases in the variance of exogenous shocks will have a more negative effect on growth.

The mainstream result in the empirical literature on government spending cyclicality is that government spending tends to be pro-cyclical in (the majority of) developing countries. Telvi and Vegh (2002) find that fiscal policy is acylical in G7 countries while it is procyclical in developing countries. Their findings are based on a sample of 56 countries during the period 1970-1994. Based on a sample of 104 countries for the period 1960-2003, Kaminsky et al. (2005) find that in OECD countries government spending is counter-cyclical while it is procyclical in developing countries. Using instrumental variables estimation, Brueckner and Gradstein (2014) show that in developing countries government spending responds strongly to persistent variation in GDP; the response of government spending to transitory variation in GDP is positive but not significantly different from zero. These authors show that transitory output shocks have a smaller effect on government spending than persistent shocks.

A strand of the literature has argued that the cyclicality of government spending depends on financial market imperfections. In particular, financing constraints prevent governments from borrowing during recessions; see Gavin and Perotti (1997). The presence of financing constraints suggests asymmetry in the response of government spending to the business cycle. Hercowitz and Strawczynski (2004) provide empirical evidence for a ratcheting effect. These authors document that in OECD countries the ratio of government spending over GDP rises during recessions and is only partially reduced during booms.

A more recent strand of the literature has argued that the cyclicality of government spending depends on institutions. Alesina et al. (2008) argue that the pro-cyclicality of government spending is related to corruption. Based on a sample of 83 countries during 1960-2003, they find that in democracies with higher levels of corruption government spending is more procyclical. The authors 
explain their finding through the lens of a political economy model where voters "starve the Leviathan" in order to reduce political rents. During a boom, voters demand more public goods and lower taxes in order to prevent corrupt politicians from appropriating tax revenues.

The results in Alesina et al. (2008) are related to Lane (2003) who estimates the response of government spending to the output gap in OECD countries. Lane finds that government spending is procyclical in OECD countries with dispersed political power.

Frankel et al. (2013) examine the response of government spending to the output gap for a set of 93 countries during 1960-2009. These authors find that country-specific coefficients characterizing the response of government spending to the output gap are negative for industrialized countries while in emerging market and developing countries these coefficients are positive, thus indicating procyclicality. Frankel et al. show that the country-specific government spending cyclicality coefficients are negatively correlated with measures of institutional quality. ${ }^{1}$ Carneiro and Garrido (2015) document that the findings in Frankel et al. are robust to expanding the sample to 180 countries during 1980-2012. Further, Carneiro and Garrido document that the findings in Frankel et al. are robust to using different filtering methods and allowing for structural breaks.

\section{Financial Development}

Aghion et al. (2010) study how credit constraints affect the impact that volatility has on economic growth. They develop a model where firms have the option to engage in short-term investment projects and long-term investment projects. Long-term investment projects differ from short-term investment projects in two important aspects: (i) long-term investment projects are characterized by a relatively less volatile long-term return; (ii) long-term investment projects have a high liquidity risk. In the absence of financial frictions, i.e. when markets are perfect, long-term investment is counter-cyclical (the cost of long-term investment is lower in recessions). When firms are faced with financing frictions, the higher liquidity risk associated with long-term investment implies that firms may only be able to start long-term investment projects during booms; i.e. financing frictions imply that long-term investment may be counter-cyclical.

A testable prediction of the Aghion et al. (2010) model is that in countries with underdeveloped financial markets, volatility has a more negative effect on growth. The mechanism

The index of institutional quality that is used in Frankel et al. is based on data provided by International Country Risk Guide on the investment profile, corruption, the rule of law, and bureaucratic quality. 
in the Aghion et al. (2010) model is through a lower share of long-term investment projects (that have a more positive effect on productivity). For a panel of 21 OECD countries during 1960-2000, the authors examine the effect of commodity price volatility on economic growth. Long-term investment projects are measured by the ratio of structural investment to total private investment. Their measure of credit constraints is the ratio of private credit to GDP. Consistent with their model's predictions the authors find that financial development mitigates the effect that volatility has on output growth.

Aghion et al. (2009) show that real exchange rate volatility has a more negative effect on economic growth in less financially developed countries. Based on a panel of 83 countries during 1960-2000, the authors find quantitatively large negative effects of exchange rate volatility on growth in countries with thin financial markets. To explain the empirical results, Aghion et al. build an open economy general equilibrium model with sticky wages and where firms face credit constraints. An exchange rate appreciation reduces firms' earnings and hence makes the credit constraint more likely to be binding. Exchange rate depreciation has the opposite effect; however, the presence of the credit constraint implies that the negative effects on output outweigh the positive effects. Consequently, the more severe credit constraints, the more negative is the effect of exchange rate volatility on growth.

\section{Estimation Strategy}

The main objective of this paper is to test the hypotheses that: (i) an increase in terms of trade volatility results in lower GDP per capita growth; (ii) the negative impact of terms of trade volatility on growth is more pronounced in less financially developed countries; and (iii) in countries where fiscal policy is more pro-cyclical. Testing these hypotheses requires cross-country time-series (panel) data on GDP per capita, financial development, and government spending. These data are available from the Penn World Tables and the World Development Indicators.

The econometric model for testing hypotheses (i)-(iii) is:

$$
\text { Growth }_{i t}=a_{i}+b_{t}+\alpha \text { Volatility }_{i t}+\beta\left(\text { Volatility }_{i t}^{*} \mathrm{FD}_{\mathrm{i}}\right)+\gamma\left(\text { Volatility }_{\mathrm{it}}{ }^{*} \text { Procyclicality }_{\mathrm{i}}\right)+\mathrm{e}_{\mathrm{it}}
$$

where Growth is the change in the natural logarithm of real GDP per capita in country i between period $t$ and $\mathrm{t}-1$. Volatility is the country-specific standard deviation of terms of trade growth. $F D$ is a measure of financial development. Following the finance literature, our main measure of financial 
development is the GDP share of domestic credit to the private sector. In order to avoid reverse causality bias (i.e. growth affects financial development), the $F D$ measure will be used in the econometric model at the beginning of the sample period. Further, the paper will present estimates where $F D$ is instrumented with legal origin. ${ }^{2}$

Procyclicality is a measure of the extent to which government spending responds to business-cycle variation in GDP. Formally $\mathrm{G}_{\mathrm{it}}=\theta_{\mathrm{i}} \mathrm{GDP}^{\text {cycl }}{ }_{\mathrm{it}}$. The parameter $\theta$ captures the pro-cyclicality of government spending. I.e. if $\theta$ is positive, then government spending increases when the cyclical component of GDP is positive (meaning, when GDP is above trend). We obtain data on $\theta$ from Frankel et al. (2013). Frankel et al. (2013) provide values of $\theta$ for a sample of 93 countries; we will use this data in the estimation of the econometric model. In order to maximize coverage of countries, we will apply the methodology of Frankel et al. to generate values of $\theta$ for countries not covered by Frankel et al. (2013).

The econometric model includes country fixed effects, $a_{\mathrm{i}}$. These fixed effects capture time-invariant country characteristics that affect economic growth, i.e. variables related to history and geography. Note that the country fixed effects account for the linear effect that $F D_{i}$ and Procyclicality $_{i}$ have on economic growth. The time fixed effects, $b_{t}$, capture common shocks that affect countries' GDP per capita growth in a given time period.

Differentiating equation (1) with respect to volatility yields:

$$
\mathrm{d}(\text { Growth }) / \mathrm{d}(\text { Volatility })=\alpha+\beta^{*} \mathrm{FD}_{\mathrm{i}}+\gamma^{*} \text { Procyclicality }_{\mathrm{i}}
$$

Hypotheses (i)-(iii) imply that $\alpha<0, \beta>0, \gamma<0$.

We note that standard errors are Huber robust and clustered at the country level. Clustering standard errors at the country level ensures that residuals are appropriately adjusted for arbitrary withincountry serial correlation (Wooldridge, 2002).

Table 1 provides a list of the variables used in the econometric analysis and their data sources. Table 2 shows bi-variate correlations. Summary statistics of the variables' first and second moments can be found in Table 3 .

2 The law and finance literature, see, for example, La Porta et al. (1998), has documented that countries' legal origin is an important determinant of cross-country differences in financial development. La Porta et al. argued that common law ensures a greater protection of private property (relative to civil law). Protection of private property is paramount for investment and the development of the financial sector. La Porta et al. document for a cross-section of countries that financial development is significantly higher in countries with common law. 


\section{Empirical Results}

Before we discuss the results from the econometric analysis, it is useful to first illustrate graphically the relationship between volatility and economic growth. Figure 3 plots on the y-axis countries' average GDP per capita growth (over five years); on the x-axis is the standard deviation of the terms of trade growth rate (also computed over a five year period). We see that for a sample of 175 countries terms of trade volatility has a negative average effect on economic growth. The coefficient from a bivariate regression that corresponds to the plot in Figure 3 is -0.31 ; this coefficient is significant at the 1 percent level (p-value 0.007).

In Figure 4 we plot the relationship between economic growth and terms of trade volatility based on cross-country time-series variation in these variables, conditional on country and time fixed effects. The scatter plots do not point to a systematic within-country relationship between economic growth and terms of trade volatility. Indeed, the slope coefficient is not significantly different from zero at the conventional significance levels ( $p$-value above 0.1 ).

Table 4 reports estimates of the average effect that terms of trade volatility has on economic growth, based on a static panel data model. Column (1) reports unconditional estimates; column (2) adds to the regression time fixed effects; column (3) includes in the econometric model country fixed effects; and column (4) shows estimates based on an econometric model that includes both time and country fixed effects.

Model specifications that do not include country fixed effects, i.e. columns (1) and (2), show a significant negative average relationship between terms of trade volatility and economic growth. The estimated relationship should be interpreted as countries with lower terms of trade volatility having systematically higher GDP per capita growth. The coefficient of -0.34 suggests that the cross-country relationship between terms of trade volatility and economic growth is sizable. For example, the model predicts that economic growth is lower by around 0.6 percentage points per annum when taking a country from the $25^{\text {th }}$ percentile $(0.034)$ of terms of trade volatility to the $75^{\text {th }}$ percentile $(0.125)$.

Model specifications that include country fixed effects, i.e. columns (3) and (4), show that the relationship between terms of trade volatility and economic growth is quantitatively small and statistically insignificant. This suggests that a significant average effect of terms of trade volatility on economic growth is present in the cross-section of countries but not at the within-country level. Column (5) shows that the growth rate of the terms of trade has a significant positive within- 
country effect on economic growth. Hence, the first moment of terms of trade growth has a significant positive within-country effect on GDP per capita growth, on average; the effect of the second moment of terms of trade growth on GDP per capita growth is, on average, insignificant when focus is on within-country variation.

Table 5 shows that with regard to the average relationship between economic growth and terms of trade volatility, a dynamic model yields similar results to the static model that was estimated in Table 4. The dynamic panel model includes the lag of GDP per capita on the right-hand side of the estimating equation; a negative coefficient on lagged GDP per capita means that there is a convergence. In columns (1) and (2) we see that the coefficient on lagged GDP per capita is not significant. Hence, there is no cross-country convergence in GDP per capita; this is a well known result (see, for example, Mankiw et al., 1992). Columns (3) and (4) show that there is significant convergence of GDP per capita to country-specific steady states. This can be seen from the negative coefficient on GDP per capita in the model specifications that include country fixed effects. The estimated coefficient on lagged GDP per capita in model specifications with country fixed effects suggests that the per annum convergence rate to country-specific steady state is around 3 percent.

Table 6 reports estimates from an econometric model that includes an interaction term between terms of trade volatility and the GDP share of domestic credit to the private sector. Following the finance literature (La Porta et al., 1998), we use variation in the GDP share of domestic credit to the private sector that is predicted by British legal origin. As an additional variable we use distance to the equator in order to generate variation in the GDP share of domestic credit that is exogenous to economic growth. ${ }^{3}$

From columns (1) and (2) of Table 6 we see that the negative effect of terms of trade volatility is mediated by cross-country differences in financial development. The coefficient on terms trade volatility is around -0.7 and significant at the 1 percent level; the interaction term between terms of trade volatility and the GDP share of domestic credit to the private sector is around 1.6 and significant at the 5 percent level. These values imply that at median levels of financial development (GDP share of domestic credit to the private sector equal to 35 percent), terms of trade volatility has a significant negative effect on economic growth; however at higher

3 Both British legal origin and distance to the equator have a highly significant positive effect on the GDP share of domestic credit to the private sector. The F-statistic on the joint test that British legal origin and distance to the equator have no significant effect on the GDP share of domestic credit to the private sector is 34.77 ; British legal origin and distance to the equator explain about one-quarter of the variation in the sample of countries' average GDP shares of domestic credit to the private sector. 
values of financial development the effect is insignificant. ${ }^{4}$

Financial development has a positive effect on economic growth on average. This can be seen from the coefficient on the GDP share of domestic credit to the private sector. The relevant coefficient is around 0.2 and is significantly different from zero at the 1 percent level, see columns (1) and (2). This is in accordance with the finance literature where it is found that a greater GDP share of domestic credit to the private sector is on average growth enhancing. Further, we have explored using the index of financial development developed in Sahay et al. (2015); this yields results similar to those presented in Table 6, see Appendix Table $1 .^{5}$

The statistical significance of the mediating role of financial development with regard to the effect of terms of trade volatility on economic growth vanishes once country fixed effects are included in the econometric model. This is shown in columns (3)-(5) of Table 6. Although the coefficient on the interaction term remains positive, it is quantitatively smaller than in columns (1) and (2). The interaction term is, in columns (3)-(5), not significantly different from zero at the conventional significance levels. An F-test shows that the coefficients on the interaction term and on terms of trade volatility are jointly not significantly different from zero (p-value above 0.1 ). Hence, the role of financial development as a mediating factor vanishes when focus is on the within-country relationship between terms of trade volatility and economic growth.

Terms of trade volatility has a particularly large negative effect on economic growth in countries where fiscal policy is procyclical. This is shown in Tables 7 and 8. Table 7 reports estimates from an econometric model that includes an interaction term between the standard deviation of the terms of trade growth rate and the country-specific coefficients that measure the response of government spending to the business cycle. Table 8 reports estimates from an econometric model that includes in addition to the interaction between terms of trade volatility and fiscal procyclicality an interaction term between terms of trade volatility and financial development. The coefficient on the interaction between terms of trade volatility and fiscal procyclicality is negative in all specifications. In Table 7, it is significantly different from zero in specifications that include country fixed effects (columns (3)-(5)). If country fixed effects are excluded, see columns (1) and (2), the interaction between terms of trade volatility and fiscal procyclicality is individually not significantly different from zero; however, the F-test rejects the null hypothesis that the

4 The interquartile range of the GDP share of domestic credit to the private sector predicted by British legal origin and distance to the equator is $[0.25,0.46]$

5 The index of financial development developed in Sahay et al. (2015) measures depth, access, and efficiency of financial markets and institutions. 
interaction term is jointly equal to zero with the linear effect that terms of trade volatility has on economic growth. In Table 8, we see that the interaction between terms of trade volatility and fiscal procyclicality is significantly different from zero in all specifications. Moreover, the coefficients on the interactions between the GDP share of domestic credit to the private sector and terms of trade volatility are not significantly different from zero.

The difference in effect of terms of trade volatility on economic growth across differences in countries' fiscal procylicality is sizable. For example, according to the estimates in column (5) of Table 8 , for a country at the $25^{\text {th }}$ percentile of fiscal procyclicality the implied marginal effect (standard error) of terms of trade volatility on economic growth is $0.04(0.20)$; for a country at the $75^{\text {th }}$ percentile the corresponding marginal effect (standard error) is $-0.36(0.21)$.

\section{Conclusion}

This paper estimated effects of terms of trade volatility on real GDP per capita growth using panel data for a sample of 175 countries during the period 1980-2010. The average effect of terms of trade volatility on economic growth is sensitive to the inclusion of country fixed effects in the estimations. In model specifications that do not include country fixed effects, terms of trade volatility has a significant negative average effect on economic growth, but once country fixed effects are included in the model, the average effect of terms of trade volatility on economic growth is not significantly different from zero. Introducing in the model government spending cyclicality and interacting this variable with terms of trade volatility, the estimates showed that terms of trade volatility has significant negative effect on economic growth in countries where government spending is procyclical. This finding is robust to the inclusion of country fixed effects. Conditional on the mediating role of government spending cyclicality, the GDP share of domestic credit to the private sector has no significant effect on the relationship between growth and terms of trade volatility. Overall, our findings suggest that countries can significantly reduce adverse growth effects of terms of trade volatility by pursuing counteryclical fiscal policies. 


\section{References}

Acemoglu, D., S. Johnson, J. Robinson, and Y. Thaicharoen (2003). "Institutional causes, macroeconomic symptoms: volatility, crises and growth." Journal of Monetary Economics, 50(1):49-123.

Aghion, P., G.M Angeletos, A. Banerjee, and K. Manova (2010). "Volatility and Growth: Credit Constraints and Productivity Enhancing Investment." Journal of Monetary Economics 57: 246265.

Aghion, P., P. Bacchetta, R. Ranciere, and K. Rogoff (2009). "Exchange Rate Volatility and Productivity Growth: The Role of Financial Development." Journal of Monetary Economics 56: 494-513.

Aizenman, J. and N. Marion (1993). "Policy Uncertainty, Persistence and Growth." Review of International Economics 1: 145-163.

Alesina, A., F. Campante, and G. Tabellini (2008). "Why Is Fiscal Policy Often Procyclical?" Journal of the European Economic Association 5: 1006-1036

Athanasoulis, S. G., van Wincoop, E. (2000). "Growth uncertainty and risk-sharing", Journal of Monetary Economics 45:3, 477-505.

Bernanke, B. (1983). "Irreversibility, Uncertainty, and Cyclical Investment." Quarterly Journal of Economics 98: 85-106.

Bertola, G. (1994). "Flexibility, Investment, and Growth." Journal of Monetary Economics 34: 215238.

Brueckner, M. and M. Gradstein (2013). "Exogenous Volatility and the Size of Government in Developing Countries." Journal of Development Economics 105: 254-266.

Brueckner, M. and M. Gradstein (2014). "Government Spending Cyclicality: Evidence from Transitory and Persistent Shocks in Developing Countries." Journal of Development Economics 111: 107-116.

Carneiro, F. and L. Garrido (2015). "New Evidence on the Cyclicality of Fiscal Policy." World Bank Policy Research Paper 7293.

Deaton, A. (1999). "Commodity prices and growth in africa." Journal of Economic Perspectives 13(3):23-40.

Dixit, A. and R. Rafael (1994). "Switching Costs and Sectoral Adjustments in General Equilibrium with Uninsured Risk." Journal of Economic Theory 62: 48-69.

Fatas, A. and I. Mihov (2003). "The Case for Restricting Fiscal Policy Discretion." Quarterly Journal of Economics 118: 1419-1447.

Fatas, A. and I. Mihov (2013). "Policy Volatility, Institutions, and Economic Growth." Review of Economics and Statistics 95: 362-376.

Frankel, J., C. Vegh, and G. Vuletin (2013). "On Graduation from Fiscal Procyclicality." Journal of 
Gavin, M. and R. Perotti (1997) "Fiscal Policy in Latin America," NBER Macroeconomics Annual (Cambridge, Mass.: MIT Press, 1997), pp. 11-61.

Hercowitz, Z. and M. Strawczynski (2004). "Cyclical Ratcheting in Government Spending: Evidence from the OECD." Review of Economics and Statistics 86: 353-361.

Jacks, D. K. O’Rourke, and J. Williamson (2011). "Commodity price volatility and world market integration since 1700." Review of Economics and Statistics 93: 800-813.

Kaminski, G., C. Reinhart, and C. Vegh (2004). "When It Rains It Pours: Procyclical Capital Flows and Macroeconomic Policies.” NBER Macroeconomic Annual 2004, edited by Mark Gertler and Kenneth Rogoff. MIT Press.

La Porta, R., F. Lopez-de-Silanes, A. Shleifer, and R. Vishny (1998). “Law and Finance.” Journal of Political Economy 106: 1113-1155.

Lane, P. (2003). "The Cyclical Behavior of Fiscal Policy: Evidence from the OECD.” Journal of Public Economics 87: 1661-1675.

Lucas, R. (1987). Models of business cycles. Oxford: Blackwell.

Mendoza, E.. "Terms-of-trade uncertainty and economic growth." Journal of Development Economics 54:323-356.

Mankiw, G., D. Romer, and D. Weil (1992). "A Contribution to the Empirics of Economic Growth." Quarterly Journal of Economics 107: 407-437.

Pindyck, R. (1991). "Irreversibility, Uncertainty, and Investment." Journal of Economic Literature 29: $1110-48$.

Ramey, G. and V. Ramey (1995). "Cross-Country Evidence on the Link Between Volatility and Growth." American Economic Review 85 1138-1151.

Rodrik, D. (1998). "Why Do More Open Economies Have Bigger Governments." Journal of Political Economy 106: 997-1032.

Sahay, R., M. Čihák, P. N'Diaye, A. Barajas, R. Bi, D. Ayala, Y. Gao, A. Kyobe, L. Nguyen, C. Saborowski, K. Svirydzenka, and Seyed Reza Yousefi (2015). "Rethinking Financial Deepening: Stability and Growth in Emerging Markets." IMF Discussion Note SD 15/08.

Tumbarello, P., E. Cabezon, and Y. Wu (2014). "Are the Asia and Pacific Small States Different from Other Small States?" IMF Working Paper 13/123.

Turnovsky, S. and P. Chattopadhyay (2003). "Volatility and growth in developing economies: some numerical results and empirical evidence." Journal of International Economics 59:267-295 2003 .

Vegh, C. And E. Talvi (2002). "Tax base variability and procyclical fiscal policy in developing countries. Journal of Development Economics 78: 156-190. 
Figure 1. Terms of Trade Volatility

(Average Across 175 Countries)

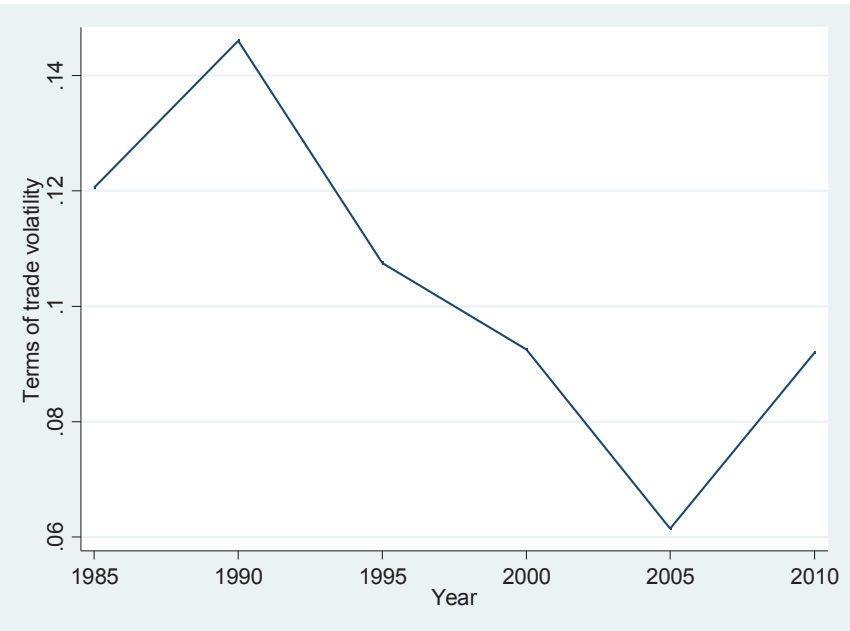

Figure 2. Terms of Trade Volatility

(Distribution of Country Averages 1980-2010)

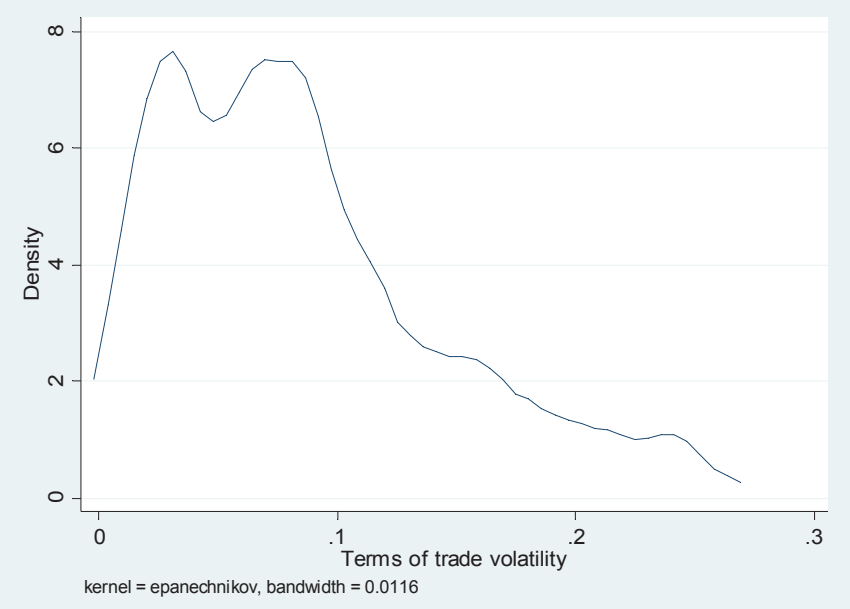


Figure 3. Economic Growth and Terms of Trade Volatility (Cross-Country Relationship)

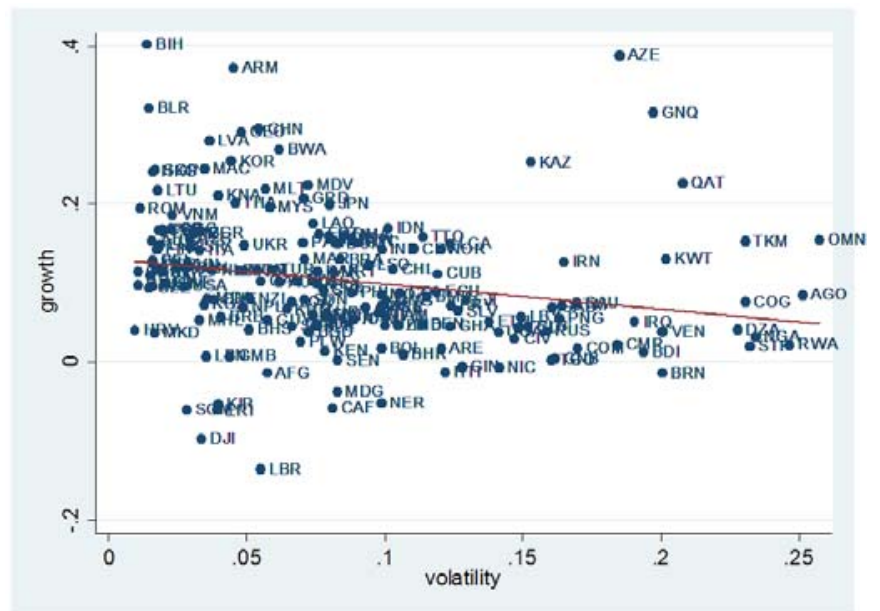

Figure 4. Economic Growth and Terms of Trade Volatility (Cross-Country Time-Series Relationship Conditional on Country and Time Fixed Effects)

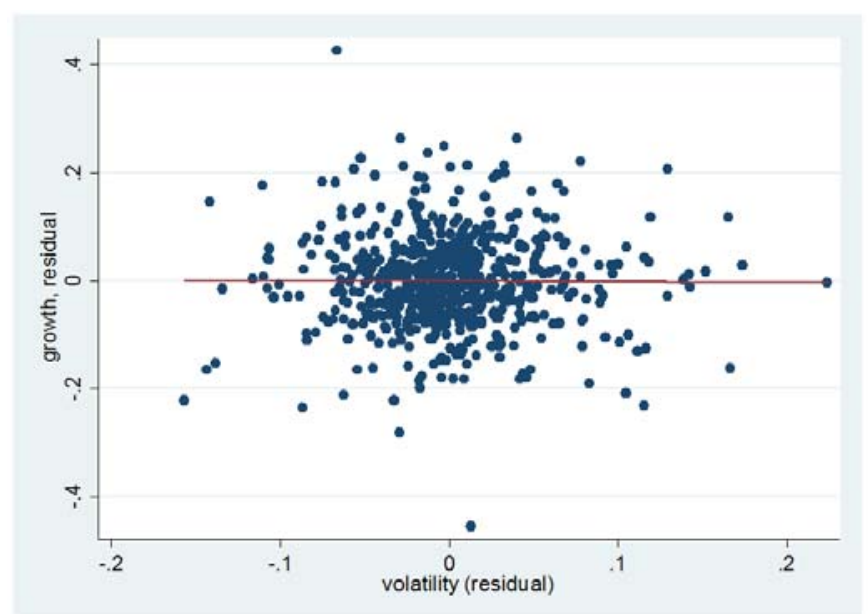




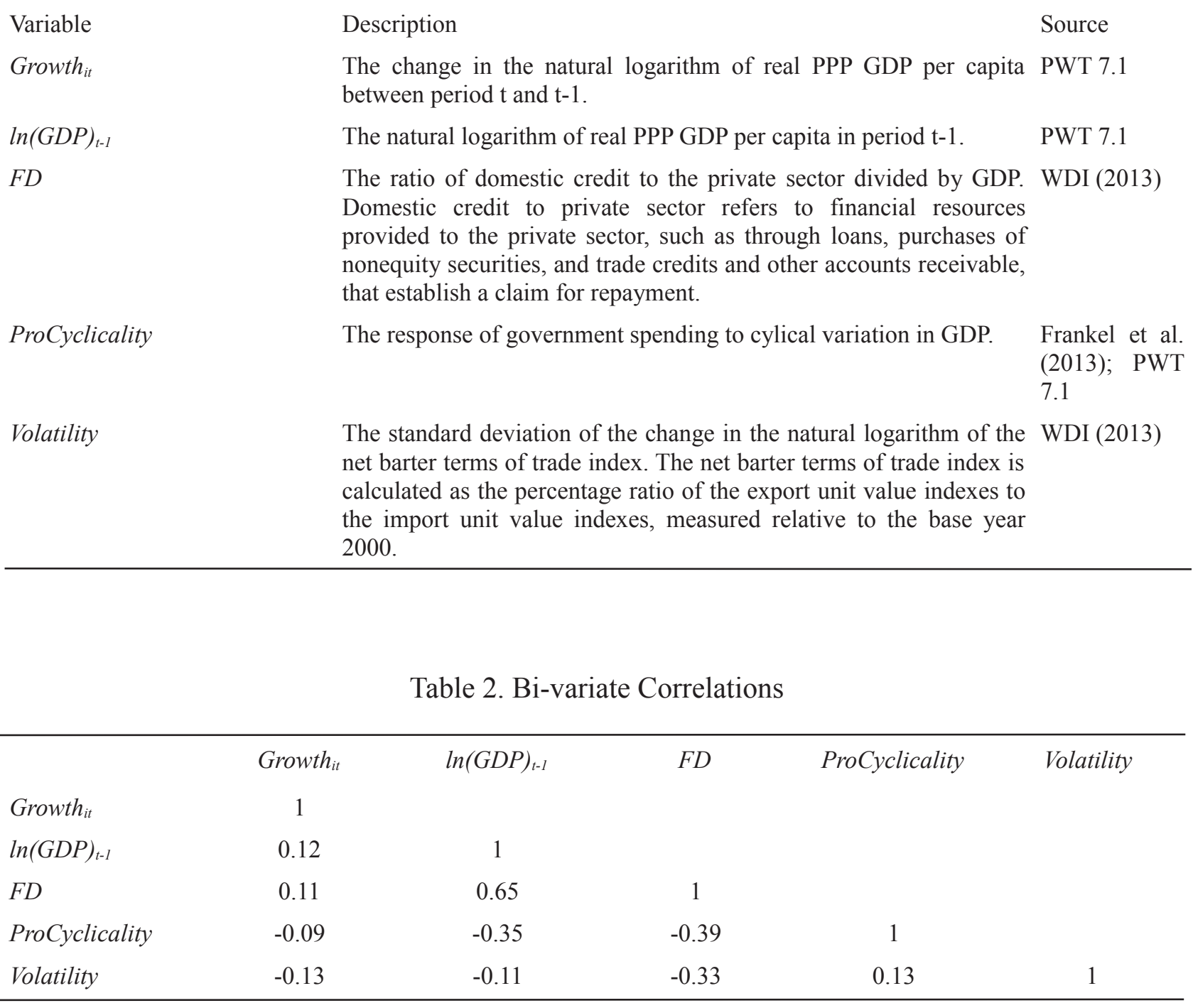

Table 3. Summary Statistics

\begin{tabular}{lccc}
\hline & Mean & Sdv & Observations \\
Growth $_{i t}$ & 0.10 & 0.16 & 632 \\
$\ln (G D P)_{t-1}$ & 8.18 & 1.25 & 632 \\
$F D$ & 0.41 & 0.41 & 632 \\
ProCyclicality & 0.34 & 0.33 & 632 \\
Volatility & 0.09 & 0.08 & 632 \\
\hline
\end{tabular}


Table 4. Economic Growth and Volatility

(Average Effect, Static Model)

\begin{tabular}{|c|c|c|c|c|c|}
\hline \multirow[t]{2}{*}{ Dependent Variable is: } & \multicolumn{5}{|c|}{ GDP per capita Growth } \\
\hline & (1) & (2) & (3) & (4) & (5) \\
\hline & LS & LS & LS & LS & LS \\
\hline Terms of Trade Volatility & $\begin{array}{c}-0.44 * * * \\
(0.08)\end{array}$ & $\begin{array}{c}-0.34 * * * \\
(0.08)\end{array}$ & $\begin{array}{l}-0.10 \\
(0.10)\end{array}$ & $\begin{array}{l}-0.01 \\
(0.09)\end{array}$ & $\begin{array}{l}-0.05 \\
(0.09)\end{array}$ \\
\hline Terms of Trade Growth & & & & & $\begin{array}{c}0.11 * * * \\
(0.03)\end{array}$ \\
\hline R-Squared & 0.06 & 0.15 & 0.06 & 0.12 & 0.15 \\
\hline Country Fixed Effects & No & No & Yes & Yes & Yes \\
\hline Time Fixed Effects & No & Yes & No & Yes & Yes \\
\hline
\end{tabular}

Table 5. Economic Growth and Volatility

(Average Effect, Dynamic Model)

\begin{tabular}{|c|c|c|c|c|c|c|}
\hline \multirow[t]{2}{*}{ Dependent Variable is: } & \multicolumn{6}{|c|}{ GDP per capita Growth } \\
\hline & (1) & (2) & (3) & (4) & $(5)$ & (6) \\
\hline & LS & LS & LS & LS & LS & SYS-GMM \\
\hline Terms of Trade Volatility & $\begin{array}{c}-0.39 * * * \\
(0.08)\end{array}$ & $\begin{array}{c}-0.33 * * * \\
(0.09)\end{array}$ & $\begin{array}{l}-0.10 \\
(0.09)\end{array}$ & $\begin{array}{c}0.04 \\
(0.09)\end{array}$ & $\begin{array}{c}0.00 \\
(0.09)\end{array}$ & $\begin{array}{l}-0.02 \\
(0.07)\end{array}$ \\
\hline Terms of Trade Growth & & & & & $\begin{array}{c}0.10 * * * \\
(0.03)\end{array}$ & $\begin{array}{c}0.08 * * * \\
(0.02)\end{array}$ \\
\hline Lagged GDP per capita & $\begin{array}{c}0.01 * * \\
(0.01)\end{array}$ & $\begin{array}{c}0.00 \\
(0.01)\end{array}$ & $\begin{array}{l}-0.05 \\
(0.04)\end{array}$ & $\begin{array}{c}-0.15 * * * \\
(0.05)\end{array}$ & $\begin{array}{c}-0.15 * * * \\
(0.05)\end{array}$ & $\begin{array}{l}-0.17 \\
(0.11)\end{array}$ \\
\hline Country Fixed Effects & No & No & Yes & Yes & Yes & Yes \\
\hline Time Fixed Effects & No & Yes & No & Yes & Yes & Yes \\
\hline
\end{tabular}

Note: The method of estimation is least squares. Huber robust standard errors (shown in parentheses) are clustered at the country level. *Significantly different from zero at the 10 percent significance level, $* * 5$ percent significance level, *** 1 percent significance level. 
Table 6. Economic Growth, Financial Development, and Volatility

\begin{tabular}{|c|c|c|c|c|c|}
\hline \multirow[t]{2}{*}{ Dependent Variable is: } & \multicolumn{4}{|c|}{ GDP per capita Growth } & \multirow[b]{2}{*}{ (5) } \\
\hline & (1) & (2) & (3) & (4) & \\
\hline & LS & LS & LS & LS & LS \\
\hline Terms of Trade Volatility [A] & $\begin{array}{c}-0.68 * * * \\
(0.17)\end{array}$ & $\begin{array}{c}-0.71 * * * \\
(0.16)\end{array}$ & $\begin{array}{l}-0.33 \\
(0.25)\end{array}$ & $\begin{array}{l}-0.30 \\
(0.20)\end{array}$ & $\begin{array}{l}-0.38^{*} \\
(0.19)\end{array}$ \\
\hline $\begin{array}{l}\text { Terms of Trade Volatility*Credit-to- } \\
\text { GDP ratio }[\mathrm{B}]\end{array}$ & $\begin{array}{l}1.60 * * \\
(0.63)\end{array}$ & $\begin{array}{c}2.17 * * * \\
(0.58)\end{array}$ & $\begin{array}{c}0.69 \\
(0.96)\end{array}$ & $\begin{array}{c}1.28 \\
(0.89)\end{array}$ & $\begin{array}{c}0.89 \\
(0.66)\end{array}$ \\
\hline Credit-to-GDP ratio & $\begin{array}{c}0.26 * * * \\
(0.06)\end{array}$ & $\begin{array}{c}0.23 * * * \\
(0.06)\end{array}$ & & & \\
\hline Terms of Trade Growth & & & & & $\begin{array}{c}0.08 * * * \\
(0.02)\end{array}$ \\
\hline Test $[A]=[B]=0, p$-value & 0.00 & 0.00 & 0.16 & 0.33 & 0.12 \\
\hline Country Fixed Effects & No & No & Yes & Yes & Yes \\
\hline Time Fixed Effects & No & Yes & No & Yes & Yes \\
\hline
\end{tabular}

Note: The method of estimation is least squares. Huber robust standard errors (shown in parentheses) are clustered at the country level. *Significantly different from zero at the 10 percent significance level, $* * 5$ percent significance level, $* * * 1$ percent significance level. 
Table 7. Economic Growth, Fiscal Procyclicality, and Volatility

\begin{tabular}{lccccc}
\hline Dependent Variable is: & \multicolumn{5}{c}{ GDP per capita Growth } \\
\hline & $(1)$ & $(2)$ & $(3)$ & $(4)$ & $(5)$ \\
& LS & LS & LS & LS & LS \\
Terms of Trade Volatility [A] & $-0.46^{* * *}$ & $-0.38^{* * *}$ & -0.12 & -0.02 & -0.03 \\
& $(0.08)$ & $(0.08)$ & $(0.09)$ & $(0.09)$ & $(0.09)$ \\
Terms of Trade Volatility*Fiscal & -0.31 & -0.32 & $-0.75^{* *}$ & $-0.68^{* *}$ & $-0.66^{* *}$ \\
Procyclicality [B] & $(0.28)$ & $(0.23)$ & $(0.30)$ & $(0.27)$ & $(0.28)$ \\
Fiscal Procyclicality & -0.00 & 0.01 & & & \\
& $(0.03)$ & $(0.03)$ & & & $0.10^{* * *}$ \\
Terms of Trade Growth & & & & $0.03)$ \\
& & & & 0.04 & 0.06 \\
Test [A]=[B]=0, p-value & 0.00 & 0.00 & 0.04 & Yes & Yes \\
Country Fixed Effects & No & No & Yes & Yes & Yes \\
Time Fixed Effects & No & Yes & No &
\end{tabular}

Note: The method of estimation is least squares. Huber robust standard errors (shown in parentheses) are clustered at the country level. *Significantly different from zero at the 10 percent significance level, $* * 5$ percent significance level, $* * * 1$ percent significance level. 
Table 8. Economic Growth, Financial Development, Fiscal Procyclicality, and Volatility

\begin{tabular}{|c|c|c|c|c|c|}
\hline \multirow[t]{2}{*}{ Dependent Variable is: } & \multicolumn{4}{|c|}{ GDP per capita Growth } & \multirow[b]{2}{*}{ (5) } \\
\hline & (1) & (2) & (3) & (4) & \\
\hline & LS & LS & LS & LS & LS \\
\hline Terms of Trade Volatility & $\begin{array}{c}-0.46^{* *} \\
(0.18)\end{array}$ & $\begin{array}{c}-0.37^{* *} \\
(0.18)\end{array}$ & $\begin{array}{l}-0.38^{*} \\
(0.21)\end{array}$ & $\begin{array}{l}-0.06 \\
(0.21)\end{array}$ & $\begin{array}{c}0.05 \\
(0.22)\end{array}$ \\
\hline $\begin{array}{l}\text { Terms of Trade Volatility*Fiscal } \\
\text { Procyclicality }\end{array}$ & $\begin{array}{l}-0.52 * \\
(0.24)\end{array}$ & $\begin{array}{l}-0.41^{*} \\
(0.21)\end{array}$ & $\begin{array}{l}-0.70^{* *} \\
(0.29)\end{array}$ & $\begin{array}{c}-0.67 * * \\
(0.27)\end{array}$ & $\begin{array}{c}-0.67 * * \\
(0.27)\end{array}$ \\
\hline $\begin{array}{l}\text { Terms of Trade Volatility*Credit-to- } \\
\text { GDP ratio }\end{array}$ & $\begin{array}{c}0.55 \\
(0.56)\end{array}$ & $\begin{array}{c}0.37 \\
(0.51)\end{array}$ & $\begin{array}{c}0.98 \\
(0.65)\end{array}$ & $\begin{array}{c}0.16 \\
(0.61)\end{array}$ & $\begin{array}{l}-0.30 \\
(0.66)\end{array}$ \\
\hline Fiscal Procyclicality & $\begin{array}{c}0.04 \\
(0.04)\end{array}$ & $\begin{array}{c}0.01 \\
(0.01)\end{array}$ & & & \\
\hline Credit-to-GDP ratio & $\begin{array}{c}0.27 * * * \\
(0.05)\end{array}$ & $\begin{array}{c}0.20^{* * *} \\
(0.05)\end{array}$ & & & \\
\hline Terms of Trade Growth & & & & & $\begin{array}{c}0.10^{* * *} \\
(0.03)\end{array}$ \\
\hline Country Fixed Effects & No & No & Yes & Yes & Yes \\
\hline Time Fixed Effects & No & Yes & No & Yes & Yes \\
\hline
\end{tabular}


Appendix Table 1. Financial Development Index from Sahay et al. (2015)

Dependent Variable is: GDP per capita Growth

\begin{tabular}{|c|c|c|c|c|c|}
\hline & (1) & (2) & (3) & (4) & $(5)$ \\
\hline & LS & LS & LS & LS & LS \\
\hline Terms of Trade Volatility & $\begin{array}{c}-0.70 * * * \\
(0.19)\end{array}$ & $\begin{array}{c}-0.74 * * * \\
(0.17)\end{array}$ & $\begin{array}{l}-0.32 \\
(0.27)\end{array}$ & $\begin{array}{l}-0.30 \\
(0.22)\end{array}$ & $\begin{array}{l}-0.21 \\
(0.23)\end{array}$ \\
\hline Terms of Trade Volatility*FD Index & $\begin{array}{c}2.42^{* *} \\
(0.98)\end{array}$ & $\begin{array}{c}3.29 * * * \\
(0.93)\end{array}$ & $\begin{array}{c}0.93 \\
(1.44)\end{array}$ & $\begin{array}{c}1.81 \\
(1.34)\end{array}$ & $\begin{array}{c}1.07 \\
(1.31)\end{array}$ \\
\hline FD Index & $\begin{array}{c}0.42 * * * \\
(0.09)\end{array}$ & $\begin{array}{c}0.36 * * * \\
(0.26)\end{array}$ & & & \\
\hline Terms of Trade Growth & & & & & $\begin{array}{c}0.10 * * * \\
(0.03)\end{array}$ \\
\hline Country Fixed Effects & No & No & Yes & Yes & Yes \\
\hline Time Fixed Effects & No & Yes & No & Yes & Yes \\
\hline
\end{tabular}

Note: The method of estimation is least squares. Huber robust standard errors (shown in parentheses) are clustered at the country level. *Significantly different from zero at the 10 percent significance level, $* * 5$ percent significance level, $* * * 1$ percent significance level. 